\title{
Structure and ACE-Inhibitory Activity of Peptides Derived from Hen Egg White Lysozyme
}

\section{Mina Memarpoor-Yazdi, Ahmad Asoodeh \& JamshidKhan Chamani}

International Journal of Peptide Research and Therapeutics

formerly known as "Letters in Peptide Science"

ISSN 1573-3149

Volume 18

Number 4

Int J Pept Res Ther (2012) 18:353-360

DOI 10.1007/s10989-012-9311-2
INTERNATIONAL JOURNAL OF

Peptide Research and Therapeutics

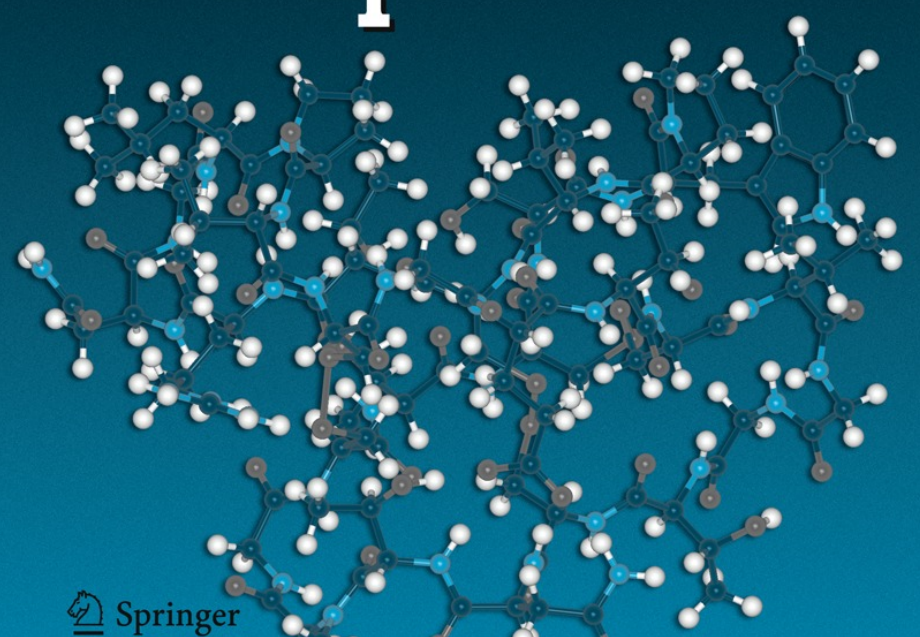

\section{囪 Springer}


Your article is protected by copyright and all rights are held exclusively by Springer Science+Business Media, LLC. This e-offprint is for personal use only and shall not be selfarchived in electronic repositories. If you wish to self-archive your work, please use the accepted author's version for posting to your own website or your institution's repository. You may further deposit the accepted author's version on a funder's repository at a funder's request, provided it is not made publicly available until 12 months after publication. 


\title{
Structure and ACE-Inhibitory Activity of Peptides Derived from Hen Egg White Lysozyme
}

\author{
Mina Memarpoor-Yazdi • Ahmad Asoodeh • \\ JamshidKhan Chamani
}

Accepted: 8 June 2012/Published online: 20 June 2012

(C) Springer Science+Business Media, LLC 2012

\begin{abstract}
Angiotensin I-converting enzyme plays an important role in hypertension and therefore its inhibition is considered to be a useful procedure in the prevention of hypertension. Two novel ACE inhibitory peptides were purified and identified from the papain-trypsin hydrolysate of hen egg white lysozyme using reverse phase-high performance liquid chromatography. The sequences of identified peptides were NTDGSTDYGILQINSR (MW: $1,753.98 \pm 0.5 \mathrm{Da})$ and VFGR (MW: $459.26 \pm 0.5 \mathrm{Da}$ ), which were named F2 and F9 peptide, respectively. Analyses of the far-UV CD spectra of ACE in the absence and presence of the F2 peptide revealed ACE secondary structural changes. In the presence of the F2 peptide, a loss of helical content of ACE was observed, which can lead to decrease of the enzymatic activity. Lineweaver-Burk plots show that the identified peptides both act as non-competitive ACE inhibitors. These findings would be helpful on the understanding of interaction between ACE and its inhibitory peptides.
\end{abstract}

Keywords RP-HPLC - ACE inhibitory activity · Inhibition pattern - Circular dichroism spectroscopy

M. Memarpoor-Yazdi · J. Chamani

Department of Biology, Faculty of Sciences, Mashhad Branch, Islamic Azad University, Mashhad, Iran

A. Asoodeh $(\bowtie)$

Department of Chemistry, Faculty of Sciences, Ferdowsi

University of Mashhad, Mashhad, Iran

e-mail: asoodeh@um.ac.ir

A. Asoodeh

Cellular and Molecular Research Group, Institute of

Biotechnology, Ferdowsi University of Mashhad, Mashhad, Iran

\author{
Abbreviations \\ ACE Angiotensin I-converting enzyme \\ FAPGG N-[3-(2-furylacryloyl-Phe-Gly-Gly)] \\ RP-HPLC Reverse phase high-performance liquid \\ chromatography \\ HEWL Hen egg white lysozyme \\ CD Circular dichroism \\ MALDI-TOF Matrix-assisted laser desorption/ionization \\ time of flight
}

\section{Introduction}

Much research has been carried out on bioactive peptides derived from food protein hydrolysates due to their potential nutraceuticals in relation to the development of functional foods (Hyun and Shin 2000). The peptides are not active within the origin protein but can be released and activated following enzymatic digestion (Phelan et al. 2009). Bioactive peptides exhibited many useful activities, such as immunoregulatory (Tsuruki et al. 2003), ACE inhibitory (FitzGerald et al. 2004), opioid (Pihlanto-Leppala 2000), antimicrobial (Mine and Kovacs-Nolan 2006), and antioxidant activities (Memarpoor-Yazdi et al. 2012; HernandezLedesma et al. 2005). Amongst these, ACE inhibitory peptides have received more attraction due to having significant effect on prevention and treatment of hypertension. ACE (angiotensin I-converting enzyme; EC 3.4.15.1) is a dipeptidyl carboxypeptidase, which plays a critical role in human renin-angiotensin system. ACE catalyses the conversion of the inactive decapeptide (angiotensin I), by cleaving a dipeptide from the C-terminus, into a potent vasoconstriction octapeptide (angiotensin II). Additionally, ACE inactivates bradykinin, which has vasodilator activity in the 
kallikrein-kinin system (Asoodeh et al. 2012). Thus, inhibition of ACE leads to an overall antihypertensive effect and therefore, is considered to be a useful procedure in the prevention and treatment of hypertension and related diseases. The first report of natural ACE inhibitory peptides was found in sank venom (Ferreira et al. 1970). Some protein hydrolysates and their purified peptides have been reported with ACE inhibitory activity. ACE inhibitory peptides have been isolated from various protein sources, such as chicken egg (Yoshii et al. 2001), fish (Matsui et al. 1994), wheat germ (Matsui et al. 1999), casein (Muruyama and Suzuki 1982), whey (Pihlanto-Leppala et al. 1998), soybean (Shin et al. 1995), and garlic (Suersuna 1998). HEWL hydrolysates have been considered to produce antioxidant (MemarpoorYazdi et al. 2012; You et al. 2010), antimicrobial (Mine et al. 2004) and ACE inhibitory peptides (Asoodeh et al. 2012). Therefore, as in other studies, HEWL can be used for production of bioactive peptides with multifunctional activity.

In this study we have characterized new peptides with the highest ACE inhibitory activity from HEWL hydrolysate. The identified peptides were synthesised and their ability to inhibit of ACE activity were investigated. We have also analysed the conformational changes of ACE structure upon interaction with the inhibitory peptide using CD spectroscopy. The inhibition mode of the identified peptides was evaluated using Lineweaver-Burk plots, and finally the kinetic parameters $\left(\mathrm{K}_{\mathrm{m}}, \mathrm{V}_{\max }\right.$, and $\left.\mathrm{K}_{\mathrm{i}}\right)$ were measured.

\section{Materials and Methods}

\section{Chemicals}

HEWL (hen egg white lysozyme) was purchased from Merck KGaA Co. [Darmstadt, Hesse, Germany]. ACE (angiotensin I converting enzyme) from rabbit lung, FAPGG (N-(3-[2-furylacryloyl-Phe-Gly-Gly])), HPLC grade acetonitrile, trypsin (from bovine pancreas), papain (from pawpaw sap) and TFA (trifluoroacetic acid) were purchased from Sigma Chemicals Co. (St. Louis, MO, USA). Semi-preparative column was purchased from MachereyNagel GmbH Co. (St. Neumann Neander, Düren, Germany). Ultrafiltration membranes with a $3 \mathrm{kDa}$ cut off were procured from Millipore (Bedford, MA, USA). All other used chemicals were of analytical grade.

Preparation of HEWL Hydrolysate and Peptide Isolation

HEWL $(4.2 \mathrm{mg} / \mathrm{mL})$ was dissolved in $50 \mathrm{mM}$ Tris- $\mathrm{HCl}$ buffer ( $\mathrm{pH} 7.5$ ) and digested by a combination of trypsin and papain with a ratio of protein substrate to each enzyme (20:1 $\mathrm{w} / \mathrm{w})$ at $37{ }^{\circ} \mathrm{C}$ for $2 \mathrm{~h}$. Each enzyme was dissolved $(0.21 \mathrm{mg} /$
$\mathrm{mL}$ ) in the same buffer, separately. After the 2-h incubation at $37^{\circ} \mathrm{C}$, the enzymatic hydrolysis was stopped by heating in boiling water for $15 \mathrm{~min}$. After the removal of insoluble materials by centrifugation $(7,000 \times g, 10 \mathrm{~min})$, the supernatant solution was transferred to fresh tubes for subsequent studies. To isolate low molecular weight peptides, the supernatant was passed through an ultra-membrane with a $3 \mathrm{kDa}$ cut off. The resulting filtrate was fractionated using a $\mathrm{C}_{18}$ semi-preparative RP-HPLC column $(10 \times 250 \mathrm{~mm}$, manufactured by Macherey-Nagel GmbH \& Co. Düren, Germany). Elution was performed using solution A $(0.1 \%$ TFA in distilled water $(\mathrm{v} / \mathrm{v}))$ combined with a 5-50 \% gradient of solution B (0.098 \% TFA in acetonitrile) over a period of $45 \mathrm{~min}$, at a flow rate of $2 \mathrm{~mL} / \mathrm{min}$. The absorbance of the elution peaks was monitored at $220 \mathrm{~nm}$ using a UV detector. Major peaks were collected, lyophilized and evaluated for their ACE inhibitory ability. The most active fractions were further purified using the same RP-HPLC conditions except that the elution was conducted using a $0.8 \%$ per minute increasing gradient of solution B.

\section{ACE Inhibition Assay}

There are various methods for assessment of ACE inhibition, including spectrophotometric, fluorometric, highperformance liquid chromatographic (HPLC), radiochemical and electrophoresis. The ACE inhibitory activity was measured using spectrophotometric method, as described by Asoodeh et al. (2012). The assay mixture containing $22 \mu \mathrm{L}$ of $\mathrm{ACE}(50 \mathrm{mU} / \mathrm{mL}), 50 \mu \mathrm{L}$ of hydrolysate or peptide $(0.5 \mathrm{mg} / \mathrm{mL}), 100 \mu \mathrm{L}$ of FAPGG $(0.5 \mathrm{mM})$ and $150 \mu \mathrm{L}$ of ACE buffer (50 mM of Tris- $\mathrm{HCl} \mathrm{pH} 7.5,0.3 \mathrm{M}$ $\mathrm{NaCl}$ and $1 \mathrm{mM} \mathrm{ZnCl}{ }_{2}$ ). The control sample consisted of $22 \mu \mathrm{L}$ of $\mathrm{ACE}(50 \mathrm{mU} / \mathrm{mL}), 100 \mu \mathrm{L}$ of FAPGG and $200 \mu \mathrm{L}$ of ACE buffer. The reaction was monitored at $340 \mathrm{~nm}$ for $20 \mathrm{~min}$. The ACE inhibition was measured according to the following equation:

ACE inhibition $(\%)=\left[1-\left(\Delta \mathrm{A}_{\text {inhibitor }} / \Delta \mathrm{A}_{\text {control }}\right)\right] \times 100$

Determination of $\mathrm{IC}_{50}$ Values

Five different concentrations of inhibitory peptide were selected and evaluated for their \%ACE inhibitory activity. The $\mathrm{IC}_{50}$ values (peptide concentration needs to inhibit $50 \%$ of the ACE activity) were determined by plotting the ACE inhibition (\%) against the different peptide concentrations. Experiments were carried out in triplicate.

Determination of Molecular Mass and Amino Acid Sequencing

The most active peptides, as novel ACE inhibitory peptides from HEWL, were characterized for identification for their 
molecular mass and amino acid sequence. The sample was desalted using ZipTips (Millipore, Billerica, MA, USA) and then analysed using MALDI TOF-TOF mass spectrometer by a 5800 Proteomics Analyzer (Applied Biosystems at Proteomics International Pty. Ltd., Nedlands, Western Australia). Determination of the amino acid sequence was carried out by using de novo sequencing method. The obtained MS/MS spectra was analysed using PEAKS Studio Version 4.5 SP2 (Bioinformatics Solutions Inc., Waterloo, ON, Canada).

\section{Peptide Synthesis}

The identified peptides were synthesized by Fmoc solidphase using an Applied Biosystems Model 432A Synergy peptide synthesizer. The synthetic peptides were purified using RP-HPLC column on a $\mathrm{C}_{18}$ semi-preparative column $(10 \times 250 \mathrm{~mm}$, manufactured by Macherey-Nagel $\mathrm{GmbH}$ \& Co. Düren, Germany). The column was developed at a flow rate of $2 \mathrm{~mL} / \mathrm{min}$ by a linear gradient of acetonitrile (5-45\% for $40 \mathrm{~min}$ ) containing $0.1 \%$ TFA.

Determination of $\mathrm{IC}_{50}$ and Inhibition Pattern of the Synthetic Peptides

ACE inhibitory effects of the synthetic peptides were evaluated and expressed as $\mathrm{IC}_{50}$ values using the method described previously. Determination of the inhibition pattern on ACE activity was performed based on the method described by Asoodeh et al. (2012). Fifty microlitres of different concentrations of the FAPGG substrate $(0.6,1.2$, 1.8 and $2.4 \mathrm{mM}$ ) were used to characterize the inhibitory mechanism of the identified peptides. The enzyme activities were measured in the absence and presence of different concentrations $(0.01$ and $0.02 \mathrm{mg} / \mathrm{mL})$ of inhibitory peptides. The kinetic of ACE inhibition in the presence of the inhibitory peptides was determined by Lineweaver-Burk plots. The kinetic parameters of $\mathrm{V}_{\max }, \mathrm{K}_{\mathrm{m}}$, as well as $\mathrm{K}_{\mathrm{i}}$ (inhibitor constant) were obtained from Lineweaver-Burk and secondary plots, respectively (Palmer 2001).

\section{Circular Dichroism Spectroscopy}

Circular dichroism (CD) spectroscopy is an excellent method to analyse the conformation of proteins, peptides and their interactions in solution (Greenfield 1996). In this study, CD spectroscopy was used to analyse the ACE conformation in the absence and presence of the F2 peptide. Far-ultraviolet CD spectra were obtained with Jasco815 spectropolarimeter (Jasco, Tokyo, Japan) equipped with a Jasco 2-syringes titrator under constant nitrogen flush at room temperature. The instrument was con-trolled by Jasco's Spectra Manager ${ }^{\mathrm{TM}}$ software. The instrument was calibrated by ammonium d-10-Camphorsulfonate (Takakuwa et al. 1985). A quartz cuvette having path length of $0.5-\mathrm{mm}$ was used.

To explore changes in secondary structure of ACE, farUV CD spectra were obtained over a wavelength range of $195-250 \mathrm{~nm}$ in the absence and presence of the F2 peptide at the same conditions. CD spectra were recorded with a time constant of $2 \mathrm{~s}$, a 1-nm bandwidth, and a scanning rate of $50 \mathrm{~nm} \mathrm{~min}{ }^{-1}$. They were signal-averaged over at least five scans, and baseline corrected by subtracting the buffer spectrum (Greenfield 1996). ACE $(0.14 \mathrm{mg} / \mathrm{mL})$ was dissolved in $50 \mathrm{mM}$ Tris- $\mathrm{HCl}$, pH 7.5 containing $0.03 \mathrm{M}$ $\mathrm{NaCl}$ and $1 \mathrm{mM} \mathrm{ZnCl} 2$. The $\mathrm{F} 2$ peptide was dissolved in ACE buffer at a concentration of $0.02 \mathrm{mg} / \mathrm{mL}$. The spectra for ACE were obtained at $0.07 \mathrm{mg} / \mathrm{mL}$ and the spectra of the peptide were obtained at $0.01 \mathrm{mg} / \mathrm{mL}$. The spectra of ACE in the presence of the F2 peptide were obtained at approx. 7:1 ACE: peptide mass ratio. The spectra for ACE used as control were obtained at $0.07 \mathrm{mg} / \mathrm{mL}$.

The data were expressed as molar residue ellipticity [ $\theta]$, which is defined as $[\theta]=100 \theta_{\mathrm{obs}} / \mathrm{cl}$, where $\theta_{\mathrm{obs}}$ is the observed ellipticity in degrees, $c$ is the concentration in residue $\mathrm{mol} \mathrm{cm}{ }^{-3}$, and $l$ is the length of the light path in $\mathrm{cm}$. To evaluate the content of secondary structure elements software packages as SELCON3 (Matsuo et al. 2012), CDSSTR (Sreerama and Woody 2000) and CONTIN (Sreerama and Woody 2000) were used.

\section{Results and Discussion}

Fractionation and ACE Inhibition Assay

Different natural compounds derived from food proteins have been investigated on their ACE inhibitory activities. Some hydrolysates derived from food proteins, especially egg proteins, have been reported with ACE inhibitory activity in vivo and in vitro (Miguel and Aleixandre 2006; Miguel et al. 2007). Thus, egg proteins and their derivatives are major groups of compounds considered as potential ACE inhibitors. Hen egg white lyozyme (HEWL), which comprises $3.4 \%$ of total egg white proteins, was hydrolyzed for production of bioactive peptides. The hydrolysate obtained from the combination of trypsin and papain exhibited the highest ACE inhibitory and antioxidant activities when compared to the hydrolysates prepared by trypsin or papain, as shown in our previous studies (Memarpoor-Yazdi et al. 2012; Asoodeh et al. 2012). Therefore, the hydrolysate prepared by a combination of the two enzymes can be a rich source of multifunctional bioactive peptides, which are released by enzymatic digestion. The hydrolysate obtained by trypsinpapain was fractionated by RP-HPLC for isolation of ACE 

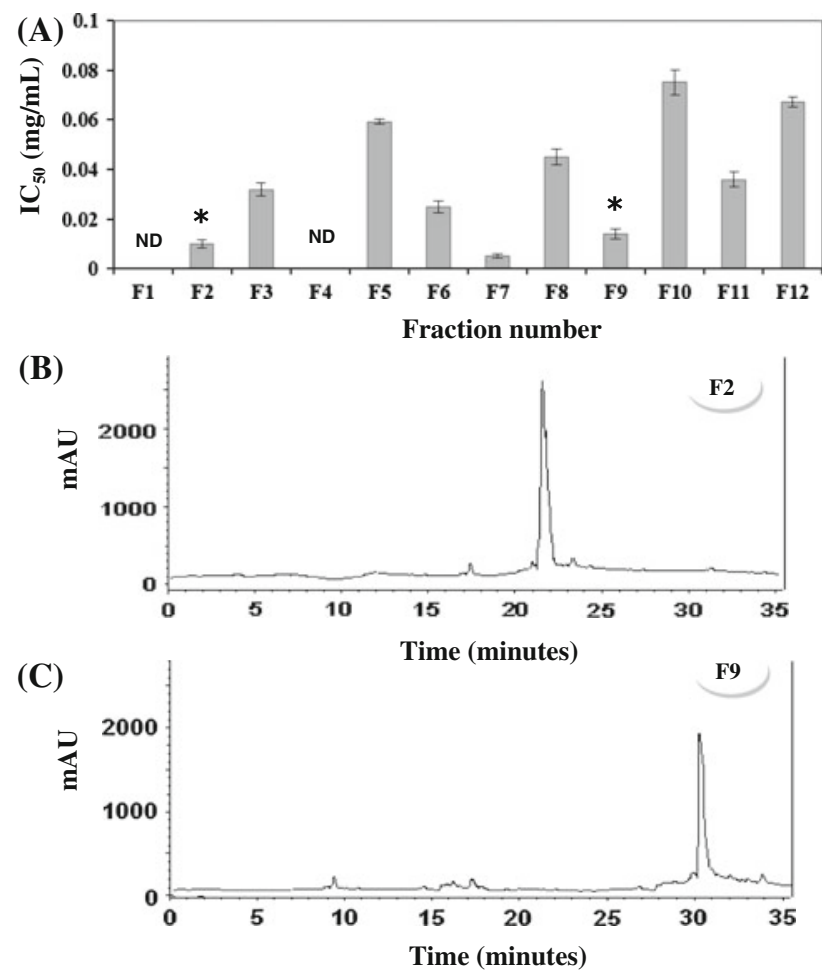

Fig. 1 a The $\mathrm{IC}_{50}$ values of isolated fractions prepared isolated from HEWL hydrolysate prepared by a combination of trypsin and papain. The F7 peptide was the first identified ACE inhibitory peptide from HEWL by Asoodeh et al. (2012). Asterisks (*) indicate the most active peptides, which were further purified to yield a single peak using the second run of $\mathrm{C}_{18}$ RP-HPLC (b and c). RP-HPLC chromatogram of all fractions has been published previously (refer to Asoodeh et al. 2012). ND none detected activity

inhibitory peptides (data not shown). The $\mathrm{IC}_{50}$ value of the prepared hydrolysate was $0.032( \pm 0.002) \mathrm{mg} / \mathrm{mL}$, while the $\mathrm{IC}_{50}$ value of the isolated fractions ranged from 0.005 to 0.075 ( \pm 0.009$) \mathrm{mg} / \mathrm{mL}$ (Fig. 1a). The most active fractions were $\mathrm{F} 7, \mathrm{~F} 2$ and $\mathrm{F} 9$ and their $\mathrm{IC}_{50}$ values were found to be $0.005,0.01$ and $0.014 \mathrm{mg} / \mathrm{mL}$, respectively.

The F7 fraction was the most active fraction obtained from the HEWL hydrolysate prepared as herein described. This has been previously reported by Asoodeh et al. (2012). However, two other fractions (F2 and F9) were also found to show important ACE inhibitory activity. Therefore, in this work we have focused on their characterization.

\section{Molecular Mass and Amino Acid Sequencing}

Two selected ACE inhibitory fractions, F2 and F9, were further purified to yield a single peak using the second run of $\mathrm{C}_{18}$ RP-HPLC (Fig. 1b, c) and identified using tandem mass spectrometry method. The amino acid composition of F2 and F9 peptides were determined as NTDGSTDYGILQINSR and VFGR (Fig. 2a-d), corresponding to fragments $46-61$ and 2-5 of HEWL, respectively. The $\mathrm{IC}_{50}$ values of the $\mathrm{F} 2$ (NTDGSTDYGILQINSR, $\mathrm{IC}_{50}=4.9$ $\mu \mathrm{M})$ and $\mathrm{F} 9$ peptides $\left(\mathrm{VFGR}, \mathrm{IC}_{50}=22.1 \mu \mathrm{M}\right.$ ) were compared with other peptides purified from the hydrolysates of ovalbumin (NIFYCP, $\mathrm{IC}_{50}=15.00 \mu \mathrm{M}$ and RVPSL, $\mathrm{IC}_{50}=20 \mu \mathrm{M}$ ) (Fujita et al. 2000; Liu et al. 2010), egg white (RADHPFL, $\mathrm{IC}_{50}=6.2 \mu \mathrm{M}$; IVF, $\mathrm{IC}_{50}=33.11 \mu \mathrm{M}$ and YAEERYPIL, $\mathrm{IC}_{50}=4.7 \mu \mathrm{M}$ ) (Miguel et al. 2004; Miguel and Aleixandre 2006), HEWL $\left(\mathrm{MKR}, \quad \mathrm{IC}_{50}=25.7 \mu \mathrm{M} ; \quad \mathrm{RGY}, \quad \mathrm{IC}_{50}=61.9 ; \quad \mathrm{VAW}\right.$, $\left.\mathrm{IC}_{50}=2.86 \mu \mathrm{M}\right) \quad($ Rao et $\quad$ al. 2012), $\alpha$-lactalbumin (WLAHK, $\quad \mathrm{IC}_{50}=77.00 \mu \mathrm{M}$ ) (Pihlanto-Leppälä et al. 2000), milk ( $\beta$-lactoglobulin) (IPA, $\mathrm{IC}_{50}=141.0 \mu \mathrm{M}$ and ALPM, IC $_{50}=928.0 \mu \mathrm{M}$ ) (Abubakar et al. 1998; Murakami et al. 2004) and bovine $\beta$-casein (SKVLPVPE, $\left.\mathrm{IC}_{50}=173.30 \mu \mathrm{M}\right)($ Yamamoto et al. 1994). The peptides identified in this study revealed more potent ACE inhibitory activity in comparison to some reports. Although, the F2 identified peptide is longer than some ACE inhibitory peptides, some other peptides derived from HEWL (Asoodeh et al. 2012), bovine $\beta$-casein ( $\mathrm{Li}$ et al. 2004), fruiting body of Pleurotus cornucopiae (Jang et al. 2011), and bonito meat (Hassan et al. 2006) had 8-17 amino acid residues. Furthermore, in previous study the F2 peptide exhibited the highest antioxidant activity compared to other purified peptides from HEWL hydrolysates (MemarpoorYazdi et al. 2012). The results of antimicrobial study showed that the F2 peptide has an antibacterial effect against Escherichia coli and Leuconostoc mesenteroides bacterial species (Memarpoor-Yazdi et al. 2012). It seems that the F2 peptide has certain benefits over those of purified peptides since it has multifunctional properties. The two proposed peptides were synthesised to determine their inhibition potential and the inhibition pattern on ACE activity. The $\mathrm{IC}_{50}$ values of the synthetic peptides were the same values as evaluated for natural purified peptides. Although, theses $\mathrm{IC}_{50}$ values are still far from value reported for captopril $(0.022 \mu \mathrm{M})$ (Aleman et al. 2011), the ACE inhibitory activity of the $\mathrm{F} 2$ peptide $\left(\mathrm{IC}_{50}=4.9 \mu \mathrm{M}\right)$ was more than enalapril $\left(\mathrm{IC}_{50}=7.3 \mu \mathrm{M}\right.$ ) (Aleman et al. 2011). It is noteworthy that in vitro digestion of this peptide by gastrointestinal digestion can produce other ACE inhibitory peptides, which may have implications for prevention of hypertension and related diseases. However, these results should also be supported by in vivo studies.

\section{Analysis}

CD spectra obtained for F2 peptide is characteristic of a helical conformation showing negative bands at 222 and $208 \mathrm{~nm}$. The evaluation of secondary structure elements revealed $96.3 \%$ alpha-helix content. ACE enzyme spectra also show predominantly helical features compatible with $68.4 \%$ alpha-helix content found in the spectra analysis 

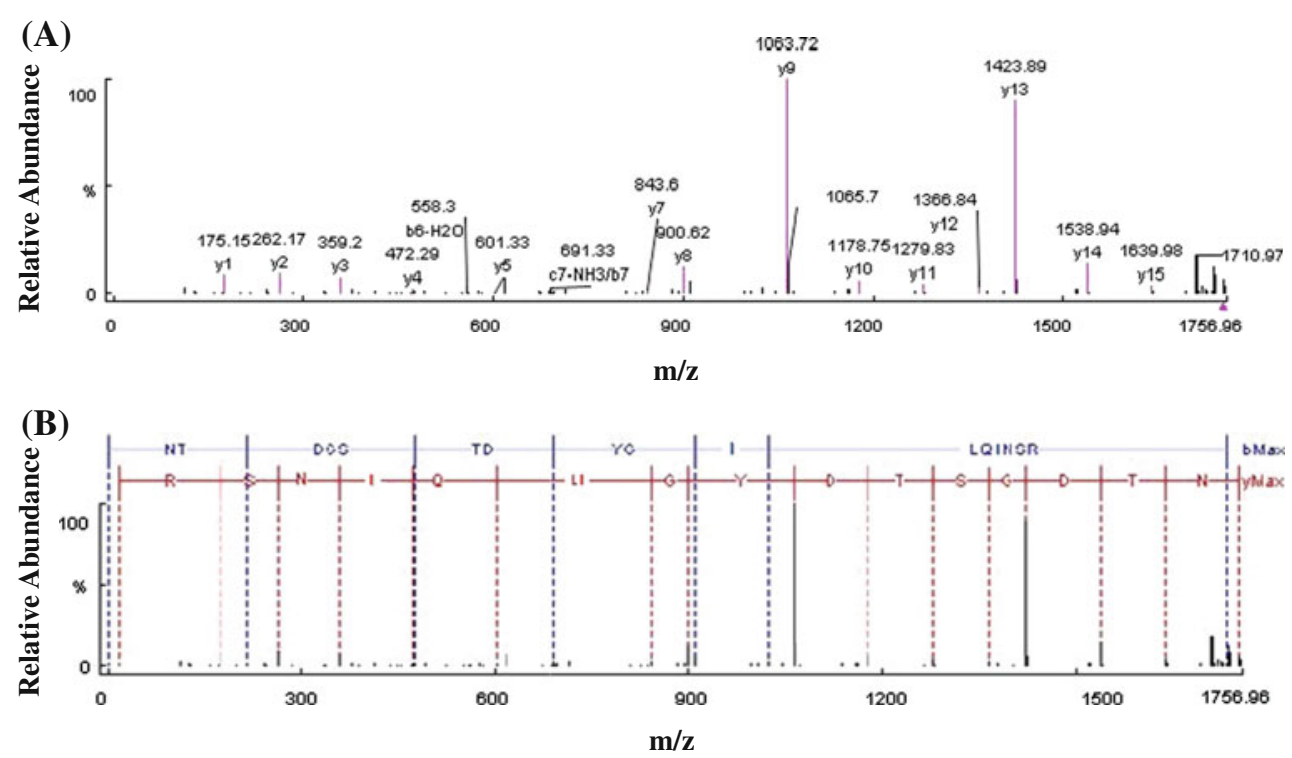

(C)

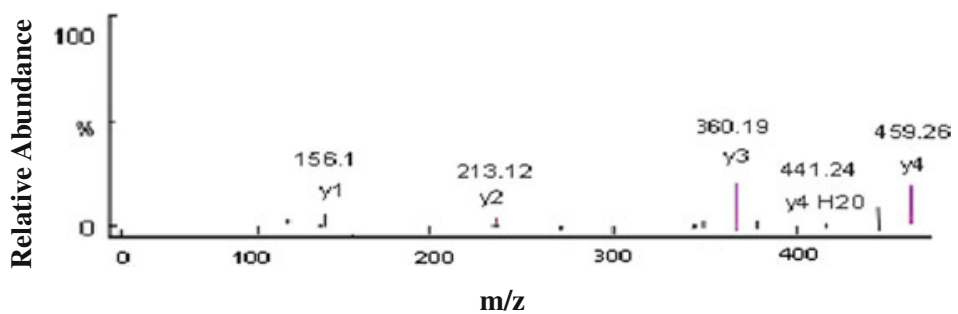

(D)

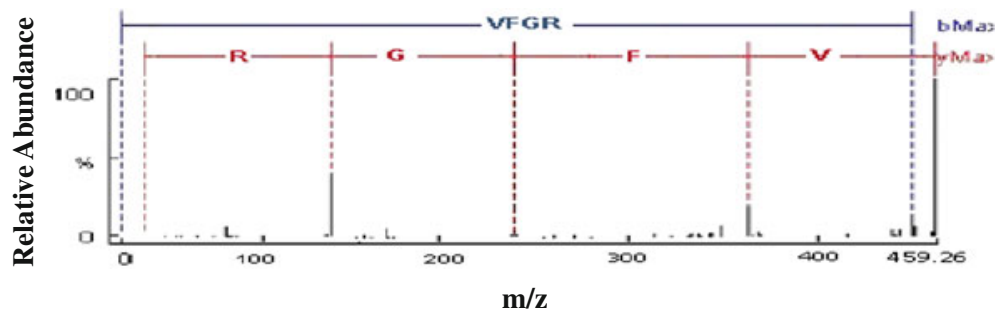

Fig. 2 Identification of the molecular mass and amino acid sequence of the F2 and F9 peptide using MALDI-TOF (Matrix-assisted laser desorption/ionization-time of flight) spectrometer. a MS/MS spectra of the F2 peptide, and $\mathbf{b}$ the interpretation of the obtained spectra. c MS/MS spectra of the F9 peptide, and $\mathbf{d}$ the interpretation of the obtained spectra

biological activity of enzymes (Vahedian-Movahed et al. 2011). Thus a decrease in the alpha-helical content of ACE at parallel to random coil formation suggests some loss of the biological activity induced by $\mathrm{F} 2$ peptide binding. The structural analysis of the F2 peptide indicated that it had $96.32 \% \alpha$-helix content.

\section{Determination of ACE Inhibition Pattern}

Although, other identified peptides from HEWL were found to be competitive (MKR, RGY and VAW) or uncompetitive (FESNFNTQATNR) inhibitors (Rao et al. 2012; Asoodeh et al. 2012), the kinetic results showed that the mechanism of ACE inhibition of the identified peptides 

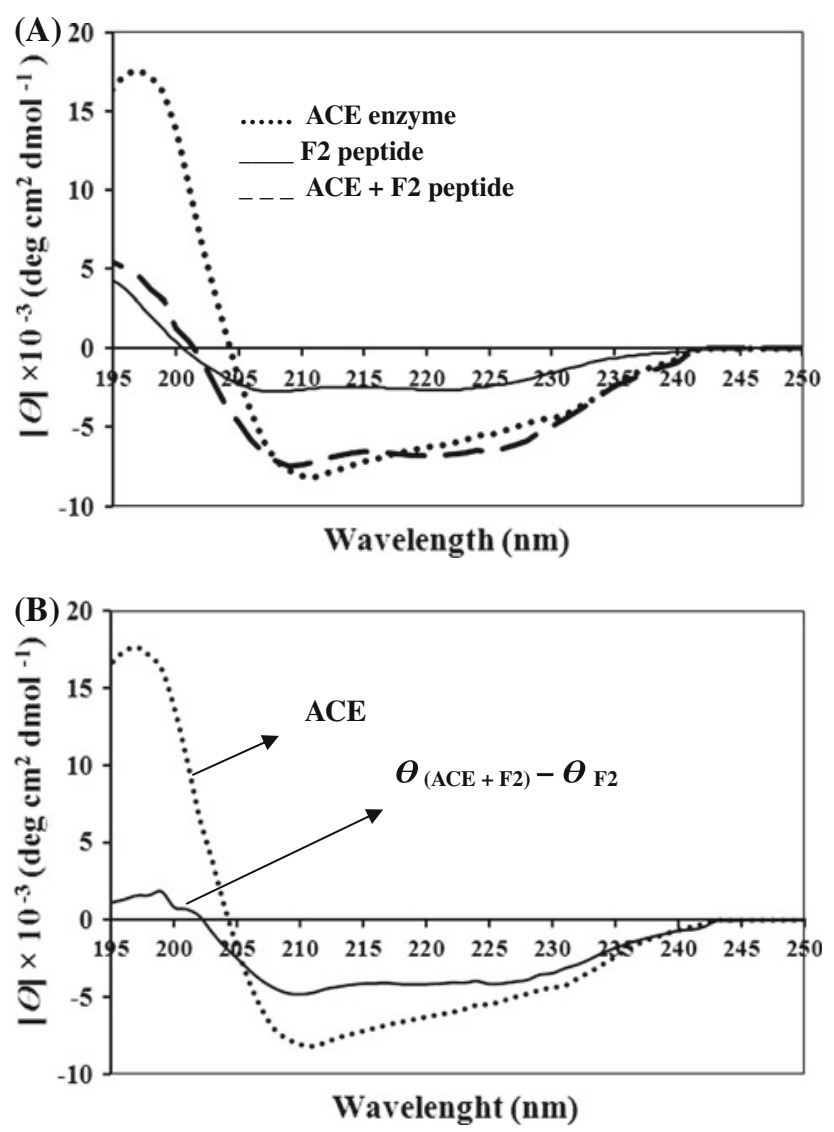

Fig. 3 a Far-UV CD spectra of the F2 peptide obtained at $0.01 \mathrm{mg} /$ $\mathrm{mL}$ and ACE enzyme obtained at $0.07 \mathrm{mg} / \mathrm{mL}$. The spectra of ACE in the presence of the F2 peptide were obtained at approx. 7:1 ACE: peptide mass ratio. Smoothing of the curves have been done with 2 score. $\mathbf{b}$ The spectra of the F2 peptide was subtracted from the spectra of the mixture (ACE-I + F2 peptide). This showed that the F2 peptide could lead to change conformation of ACE

were both non-competitive (Fig. 4a, b). This means that they bind to a site other than the substrate-binding site on the enzyme and enzyme-substrate complex (Palmer 2001), while competitive inhibitors (MKR, RGY and VAW) reported by Rao et al. (2012) can interact with the active sites of ACE and prevent substrate binding. The difference in the structure of the inhibitory peptides can lead to have various ACE inhibition patterns. Non-competitive inhibitors do not affect the combination of the substrate with the enzyme, but affect only enzyme reaction velocity (Palmer 2001). The structure of the inhibitory peptides has an important role in the ACE inhibition pattern. The presence of positively charged C-terminal arginine or lysine residues in some inhibitors can affect on ACE inhibitory activity ( $\mathrm{Li}$ et al. 2004). Some ACE inhibitor peptides with positive charge at their C-termini have been isolated from various sources, such as HEWL (FESNFNTQATNR and MKR) (Asoodeh et al. 2012; Rao et al. 2012), sardine muscle
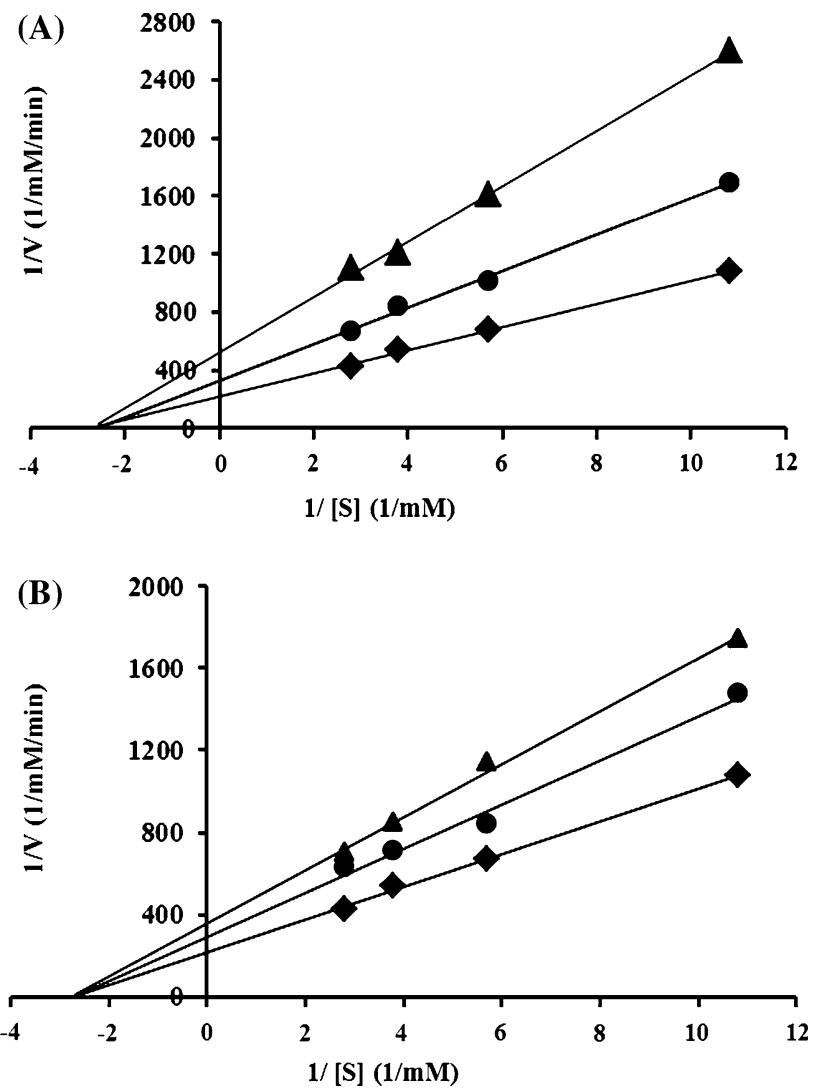

Fig. 4 a The Lineweaver-Burk plots of ACE inhibition by F2, and b F9 peptides. ACE inhibitory activity was measured in the absence or presence of the inhibitory peptides (filled diamond, control; filled circle, $0.01 \mathrm{mg} / \mathrm{mL}$; filled triangle, $0.02 \mathrm{mg} / \mathrm{mL}$ ). $1 / \mathrm{S}$ and $1 / \mathrm{V}$ indicate the reciprocal substrate concentration and velocity, respectively

(AKK) (Matsui et al. 1994), chicken muscle (FQKPKR) (Fujita et al. 2000), $\alpha$-lactalbumin (WLAHK) (PihlantoLeppälä et al. 2000), recombinant human casein (YPER) (Nakagomi et al. 2000), and human serum albumin (YLYEIAR and AFKAWAVAR) (Nakagomi et al. 1998; Nakagomi et al. 2000). Besides, there is an aliphatic residue (Val) at $\mathrm{N}$-terminal of the F9 peptide, which can contribute in its ACE inhibitory potential, as is confirmed by other studies (Li et al. 2004). Kinetic studies showed that the slope and intercept on the $1 /[\mathrm{V}]$ of a primary Lineweaver-Burk plot are altered in the presence of peptides, but intercept on the $1 /\left[\mathrm{S}_{0}\right]$ is unchanged (Fig. $4 \mathrm{a}, \mathrm{b}$ ). The inhibitor constant $\left(\mathrm{K}_{\mathrm{i}}\right)$ is determined from the intercept on the $\left[\mathrm{I}_{0}\right]$ axis of the secondary plot of $1 / \mathrm{V}_{\max ^{\prime}}\left(\mathrm{V}_{\max }\right.$ in the presence of peptide) or the slope of primary plot against $\left[\mathrm{I}_{0}\right]$ (data not shown). Table 1 shows the kinetic parameters for the F2 and F9 peptides. A large value of $\mathrm{K}_{\mathrm{i}}$ indicates a low affinity between enzyme and inhibitor. On comparing $\mathrm{K}_{\mathrm{i}}$ of the $\mathrm{F} 2(7.5 \mu \mathrm{M})$ and F9 peptide $(69.7 \mu \mathrm{M})$, it will be evident that the $\mathrm{F} 2$ peptide acts as a non-competitive inhibitor with a higher affinity to ACE. 
Table 1 The kinetic parameters for the F2 and F9 peptides were measured and compared to the control

\begin{tabular}{lllllc}
\hline & Control & $\begin{array}{l}\text { F2 peptide } \\
(0.01 \mathrm{mg} / \mathrm{mL})\end{array}$ & $\begin{array}{l}\text { F2 peptide } \\
(0.02 \mathrm{mg} / \mathrm{mL})\end{array}$ & F9 $(0.01 \mathrm{mg} / \mathrm{mL})$ & F9 $(0.02 \mathrm{mg} / \mathrm{mL})$ \\
\hline $\mathrm{K}_{\mathrm{m}}(\mathrm{mM})$ & 0.370 & 0.370 & 0.370 & 0.370 & 0.370 \\
$\mathrm{~V}_{\max }$ or $\mathrm{V}_{\max }{ }^{\prime a}(\mathrm{mM} / \mathrm{min})^{-1}$ & 0.0047 & 0.0030 & 0.0019 & 0.0034 & 0.0028 \\
$\mathrm{~K}_{\mathrm{i}}(\mu \mathrm{M})$ & - & 7.5 & 7.5 & 69.7 & 69.7 \\
\hline
\end{tabular}

$\mathrm{K}_{\mathrm{m}}$ is unchanged in the absence and presence of inhibitor peptide, while $\mathrm{V}_{\max }$ is altered, which shows ACE inhibition mechanisms of the peptides are both non-competitive

${ }^{a} \mathrm{~V}_{\max }$ ' is $\mathrm{V}_{\max }$ in the presence of inhibitory peptide

\section{Conclusion Remarks}

HEWL hydrolysates are known to contain bioactive peptides such as ACE inhibitory, antioxidant and antimicrobial peptides. In this study, the most active peptides were F2 (NTDGSTDYGILQINSR) and F9 (VFGR) and identified as new ACE inhibitory peptides. The purified peptides both non-competitive inhibited ACE. The results of CD spectroscopy showed that there are significant changes in ACE conformation upon the interaction with F2 peptide as denoted by an alpha-helix content decrease and a coil content increase. These changes are indicative of a mild denaturation with loss of enzymatic activity. Two identified peptides can serve as lead compounds in the preparation of functional foods and antihypertensive drugs. However, more detailed researches as an indication of their ACE inhibitory activity in vivo are required.

Acknowledgments This work was financially supported by Mashhad-Branch, Islamic Azad University and Ferdowsi University of Mashhad, Mashhad, Iran. The authors gratefully acknowledge Institute of Biotechnology, Ferdowsi University of Mashhad, Mashhad, Iran for beneficial help.

\section{References}

Abubakar A, Saito T, Kitazawa H, Kawai Y, Itoh T (1998) Structural analysis of new antihypertensive peptides derived from cheese whey protein by proteinase k digestion. J Dairy Res 81:3131-3138

Aleman A, Giménez B, Pérez-Santin E, Gómez-Guillén MC, Montero P (2011) Contribution of Leu and Hyp residues to antioxidant and ACE-inhibitory activities of peptide sequences isolated from squid gelatin hydrolysate. Food Chem 125:334-341

Asoodeh A, Memarpoor-Yazdi M, Chamani J (2012) Purification and characterisation of angiotensin I converting enzyme inhibitory peptides from lysozyme hydrolysates. Food Chem 131:291-295

Ferreira SH, Bartelt DC, Greene LJ (1970) Isolation of bradykininpotentiating peptides from Bothropsjararaca venom. Biochemistry 9:2583-2593

FitzGerald RJ, Murray BA, Walsh DJ (2004) Hypotensive peptides from milk proteins. J Nutr 134:980S-988S

Fujita H, Yokoyama K, Yoshikawa M (2000) Classification and antihypertensive activity of angiotensin I-converting enzyme inhibitory peptides derived from food proteins. J Food Sci 65:564-569
Greenfield NJ (1996) Methods to estimate the conformation of proteins and polypeptides from circular dichroism data. Anal Biochem 235:1-10

Hassan F, Kitagawa M, Kumada Y, Hashimoto N, Shiiba M, Katoh S, Terashima M (2006) Production kinetics of angiotensin-I converting enzyme inhibitory peptides from bonito meat in artificial gastric juice. Proc Biochem 41:505-511

Hernandez-Ledesma B, Davalos A, Bartolome B, Amigo L (2005) Preparation of antioxidant enzymatic hydrolysates from alphalactalbumin and beta-lactoglobulin, Identification of active peptides by HPLC-MS/MS. J Agric Food Chem 53:588-593

Hyun CK, Shin HK (2000) Utilization of bovine blood plasma proteins for the production of angiotensin I converting enzyme inhibitory peptide. Proc Biochem 36:65-71

Jang JH, Jeong SC, Kim JH, Lee YH, Ju YC, Lee JS (2011) Characterisation of a new antihypertensive angiotensin I-converting enzyme inhibitory peptide from Pleurotus cornucopiae. Food Chem 127:412-418

Li GH, Le GW, Shi YH, Shrestha S (2004) Angiotensin I-converting enzyme inhibitory peptides from food proteins and their physiological and pharmacological effects. J Nut Res 24:469486

Liu J, Yu Z, Zhao W, Lin S, Wang E, Zhang Y et al (2010) Isolation and identification of angiotensin-converting enzyme inhibitory peptides from egg white protein hydrolysates. Food Chem 122:1159-1163

Matsui T, Matsufuji H, Seki E, Osajima K, Nakashima M, Osajima Y (1994) Angiotensin I-converting enzyme inhibitory peptides in an alkaline protease hydrolysate derived from sardine muscle. Biosci Biotechnol Biochem 58:2244-2245

Matsui T, Li CH, Osajima Y (1999) Preparation and characterization of novel bioactive peptides responsible for angiotensin I-converting enzyme inhibition from wheat germ. J Pept Sci 5:289297

Matsuo K, Sakurada Y, Tate SI, Namatame H, Taniguchi M, Gekko K (2012) Secondary-structure of alcohol-denatured proteins by vacuum-ultraviolet circular dichroism spectroscopy. Proteins: structure. Funct Bioinform 80:281-293

Memarpoor-Yazdi M, Asoodeh A, Chamani J (2012) A novel antioxidant and antimicrobial peptide from hen egg white lysozyme hydrolysates. J Funct Foods 4:278-286

Miguel M, Aleixandre A (2006) Antihypertensive peptides derived from egg proteins. J Nutr 136:1457-1460

Miguel M, Recio I, Gómez-Ruiz JA, Ramos M, López-Fandiño R (2004) Angiotensin I-converting enzyme inhibitory activity of peptides derived from egg white proteins by enzymatic hydrolysis. J Food Prot 67:1914-1920

Miguel M, Manso M, Aleixandre A, Alonso MJ, Salaices M, LópezFandio R (2007) Vascular effects, angiotensin I-converting enzyme (ACE)-inhibitory activity, and antihypertensive properties of peptides derived from egg white. J Agric Food Chem 55:10615-10621 
Mine Y, Kovacs-Nolan J (2006) New insights in biologically active proteins and peptides derived from hen egg. Worlds Poul Sci J 62:87-95

Mine Y, Ma FP, Lauriau S (2004) Antimicrobial peptides released by enzymatic hydrolysis of hen egg white lysozyme. J Agric Food Chem 52:1088-1094

Murakami M, Tonouchi H, Takahashi R, Kitazawa H, Kawai Y, Negishi $\mathrm{H}$ et al (2004) Structural analysis of a new antihypertensive peptide (b-lactosin B) isolated from a commercial whey product. J Dairy Res 87:1967-1974

Muruyama S, Suzuki H (1982) A peptide inhibitor of angiotensin I converting enzyme in the tryptic hydrolysate of casein. Agric Biol Chem 46:1393-1394

Nakagomi K, Fujimura A, Ebisu H, Sakai T, Sadkane Y, Fuji N, Tanimura T (1998) Acein-1, a novel angiotensin-I-converting enzyme inhibitory peptide isolated from tryptic hydrolysate of human plasma. FEBS Lett 438:225-257

Nakagomi K, Ebisu H, Sadakane Y, Fujii N, Akizawa T, Tnimura T (2000) Properties and human origine of two angiotensin I-converting enzyme inhibitory peptides isolated from a tryptic hydrolysate of human serum albumin. Biol Pharm Bull 23:879-883

Natesh R, Schwager SL, Sturrock ED, Acharya KR (2003) Crystal structure of the human angiotensin-converting enzyme-lisinopril complex. Nature 421:551-554

Palmer T (2001) Enzymes, biochemistry, biotechnology and clinical chemistry (1st), Chap. 8. Harwood Publishing, Chichester

Phelan M, Aherne A, FitzGerald RJ, O'Brien NM (2009) Caseinderived bioactive peptides: biological effects, industrial uses, safety aspects and regulatory status. Int Dairy J 19:643-654

Pihlanto-Leppala A (2000) Bioactive peptides derived from bovine whey proteins: opioid and ace-inhibitory peptides. Trends Food Sci Tech 11:347-356

Pihlanto-Leppala A, Rokka T, Korhonen H (1998) Angiotensin I converting enzyme inhibitory properties peptides derived from bovine milk proteins. Int Dairy J 8:325-331

Pihlanto-Leppälä A, Koskinen P, Phlola K, Tupasela T, Korhonen H (2000) Angiotensin I-converting enzyme inhibitory properties of whey protein digests: concentration and characterization of active peptides. J Dairy Res 67:53-64

Rao SQ, Ju T, Sun J, Su YJ, Xu RR, Yang YJ (2012) Purification and characterization of angiotensin I-converting enzyme inhibitory peptides from enzymatic hydrolysate of hen egg white lysozyme. Food Res Int 46:127-134

Shin ZI, Ahn CW, Nam HS, Lee HJ, Moon TH (1995) Fractionation of angiotensin converting enzyme inhibitory peptide from soybean paste. Korean J Food Sci Technol 27:30-234

Sreerama N, Woody RW (2000) Estimation of protein secondary structure from circular dichroism spectra: comparison of CONTIN, SELCON, and CDSSTR methods with an expanded set. Anal Biochem 287:252-260

Suersuna K (1998) Isolation and characterization of angiotensin I-converting enzyme inhibitor dipeptide derived from Allium sativum L. (garlic). J Nutr Biochem 9:415-419

Takakuwa T, Konno T, Meguro H (1985) A new standard substance for calibration of circular dichroism: ammonium d-10-camphorsulfonate. Anal Sci 1:215-218

Tsuruki T, Kishi K, Takahashi M, Tanaka M, Matsukawa T, Yoshikawa M (2003) Soymetide an immunostimulating peptide derived from soybean $\beta$-conglycinin, is an fMLP agonist. FEBS Lett 540:206-210

Vahedian-Movahed H, Saberi MR, Chamani J (2011) Comparison of binding interactions of lomefloxacin to serum albumin and serum transferrin by resonance light scattering and fluorescence quenching methods. J Biomol Struct Dyn 28:483-502

Yamamoto N, Akino A, Takano T (1994) Antihypertensive effect of the peptides derived from casein by an extracellular propeinase from Lactobacillus heveticus CP790. J Dairy Res 77:917-922

Yoshii H, Tachi N, Ohba R, Sakamura O, Takeyama H, Itani T (2001) Antihypertensive effect of ACE inhibitory oligopeptides from chicken egg yolks. Comp Biochem Physiol 128C:27-33

You SJ, Udenigwe CC, Aluko RE, Wu JP (2010) Multifunctional peptides from egg white lysozyme. Food Res Int 43:848-855 